\title{
The Prevelence of SBS and Absenteeism among Children in Urban Refurbished Private Preshools
}

\author{
Naziah Muhamad Sallehª, Nuzaihan Aras Agus Salim¹, Syahrul Nizam Kamaruzzaman² anad Norhayati \\ Mahyuddin $^{2}$, Fairus Muhammad Darus ${ }^{3}$
}

\begin{abstract}
${ }^{1}$ University Science Malaysia, School of Housing Building \& Planning, Building Technology Department, 11800 Penang, Malaysia ${ }^{2}$ University of Malaya, Faculty of Built Environment, Building Performance and Diagnostic, 50603 Kuala Lumpur
\end{abstract}

${ }^{3}$ Faculty of Applied Sciences, Universiti Teknologi MARA, Shah Alam, Selangor, Malaysia

\begin{abstract}
The preschool education is compulsory to children in Malaysia. This regulation has encouraged more premises to be refurbished as a pre-school building. This paper examines the pupils' absenteeism and the prevalence of Sick Building Symptoms (SBS) initiated in congested private preschool with different ventilation strategies. The study analysed data from the attendance record of 10 classrooms and the questionnaire surveys administered to 151 parents about their children health symptoms once they were leaving the schools building. Questions on SBS used 5-point likert scale with symptoms concern on nose, eye, head, throat, skin, breath and tiredness. The descriptive and chi-square test applied to obtain the association of SBS and ventilation strategies in the classrooms. With quantitative and qualitative explanation, the unhealthy environment in refurbished preschools explained. Running nose, coughing and sore throat frequently reported in air-conditioning (AC) classrooms. The higher absent rate found in AC classrooms. These symptoms show there were weaknesses in ventilation performance and environment in the selected preschools. Further analyses on objective measurements in future research are strongly recommended.
\end{abstract}

Keywords: Indoor Environmental Quality, Indoor Air Quality, Sick Building Symptoms, Refurbishment, Preschool, Ventilation,Class

${ }^{\mathrm{a}}$ Corresponding author: naziahmsalleh@usm.my 


\section{Introduction}

Indoor Environmental Quality (IEQ) in schools can have a substantial impact on children's health, as an important environment where children may be exposed to pollutants and allergens [1]. The school provides a major indoor environment for children away or apart from their home. Children may spend 10 hours per day at school [2] depending on the time they arrive at the school and the time they leave the school. It is special concerns as the pupils are susceptible to poor Indoor Air Quality (IAQ). Indoor contaminant may increase both long and short term health problems among pupils and staff, reduce the productivity of teachers $[3,4]$ and degrade the pupil's learning environment and comfort [5]. A significant influence from overall indoor environmental quality can effect and give the influence on student attendance and performance. Studies have shown that poor IAQ resulted more illness, absenteeism and asthma attacks.

The major exposure effects of air contaminants will be the health effects visible of the symptoms or the disease. Obviously, it influences student's performance directly or indirectly through the effects of attendance. School absenteeism is one of the main problems in public and private school. Most of the incidence for total absent episodes and percent of missed days, including those because of upper respiratory infections [6,7]. Regards to Malaysia climate, these compilations has originate immensely among children and preschooler [7-10]. Whereas it enormously affected by the weather [7], indoor air, ventilation strategies [7-9] or the surrounding environment [10].

Asthma reported to be the number one cause for student absenteeism due to chronic conditions and was the leading cause of hospitalization for children [6]. Epidemiological data indicated that $7.4 \%$ of school-age children report having asthma symptoms annually, and 2.8 million children between 5 and 14 years of age had a diagnosis of asthma [11]. Of students diagnosed with asthma that attend school, the majority of school nurses or $51 \%$ indicated asthma was more disruptive of school routine than other chronic diseases, and 53\% stated that all students with asthma were able to participate in all school day activities including gym and/or recess, and keep up with their peers (American Lung Association, 2003). This also mentioned in local studies where asthma and respiratory health affected the schoolchildren attendance $[7,8]$.

Eventually, asthma was not the single contributing factor to student absenteeism. Outbreaks of acute infections caused by viruses, bacteria, parasites, and protozoa were documented among both students and staff in schools [12]. These types of sicknesses occurred throughout the school year and impacted on student absenteeism, which in turn influences student performance. Infectious disease was spread through person-to-person contact, by droplets or large particles spread by coughing, sneezing, or wheezing, or by fomites (self-innoculation after touching contaminated surfaces), the school building factors that influenced the transmission of infectious disease include the respiratory particles, ventilation rate, humidity, location of the building, ventilation modes, school facilities and functional state of sinks and toilets [7,8,13]. Design specifications related to indoor airflow, HVAC systems, windows, and controlled air ventilation were all factors that improved the quality of the indoor environment in school facilities $[7,13]$. The 17 separate studies found positive health impacts measured by reduction in reported prevalence of symptoms of asthma, flu, sick building syndrome, respiratory problems, and headaches [14].

The escalating numbers of children requiring preschool education in Malaysia has encouraged the involvement of private initiatives to meet the demand [15]. Thus, the government has encouraged more private preschool centers to be set up, involving various types of refurbished buildings with various types of property converted into classrooms to accommodate 20 to 30 pupils at a time. This, presents a challenge in providing adequate IAQ in congested areas and locations since most of the private preschools are housed in refurbished residential and commercial buildings. Some IAQ parameters are resulted from the numbers of occupants, space and the ventilation competencies. Somehow, there is a dearth information on pupils' performance in relation of SBS and absenteeism in these type of adaptive-reused building. Thus, the objective of this study are accordingly: i) Evaluate the performance of occupants/pupils in terms of health symptoms and annual attendance towards IAQ conditions in refurbished preschools, and ii) to compare the health symptoms annual absentees in different ventilation modes classrooms.

\section{Materials and methods}

Monitoring performed in 10 classrooms randomly selected (of the 5 schools) the schools are located in different districts but in $25 \mathrm{~km}$ radius with each other's. The selections of the schools were based on the similarities of learning and activities systems, foods types serve during recess and school hours. All the classrooms were operating in double storey terrace house $\left(100 \mathrm{~m}^{2}\right)$. Majority of the classrooms was a bedroom. The walkthrough observation of the building (Table 1) has indicated all the buildings have located in urban, residential area and at the roadside. The environment might enclose to the other factors which 
can contribute to health effects. Anyhow, the distances of the main road to the buildings are varying. 4 of the classrooms are air conditioning and the other 6 classrooms are natural ventilated with ceiling fan and windows open. The whole classrooms were installed with one ceiling fan each.

The continuous monitoring of indoor and outdoor for temperature, relative humidity, carbon monoxide, carbon dioxide and air speed were all obtained using Gray Wolf Sensing Solution IQ604 Indoor Air QualityProbe(Gray Wolf sensing Solution, Shelton, CT, USA). Due to the limited instruments, YESAIR 8Channel IAQ Monitor was used to measure only indoor formaldehyde, nitrogen oxide and ozone. Each monitor was calibrated by the factory once within the calendar year and monthly by the field research team.

In addition, the DUST Track Technology model TSI 8532 utilised to measure indoor particulate matter $\left(\mathrm{PM}_{10}\right)$. The detection range was $0.001-150 \mathrm{mg} / \mathrm{m} 3$ and the resolution was $0.1 \%$ of the reading. The log interval of the concentration data was set at every 60 seconds. Although the particle size range of the instrument was 0.1-10 mm, but during these measurements a sizeselective impactor was attached to the inlet (with a cut size of $10 \mu \mathrm{m}$ ), which pre-conditioned the size range of particles $(10 \mu \mathrm{m})$ entering the instrument. The particle monitor was able to detect particle emission concentration within the range of $0.001-150 \mathrm{mg} / \mathrm{m} 3$ under the particle size range of $0.1-10 \mu \mathrm{m}$ and operational temperature range of $0-50^{\circ} \mathrm{C}$.

Measurement done in three days of each classroom because of the following reason: (1)three as the optimal sample size (verify the mean and the frequency, to identify the valid minimum and maximum results), (2) sampling could be repeated if the instrument fail to measure . It were logging at every 1 minute of measurement. Atleast 8 hours per day of measurement - (the minimum of exposure to pollutants in determining SBS) (CIBSE Guide A, 2006). Measurements start at 7.30 p.m (atleast 30 minutes before the class starts) and end at 4.30 p.m. The monitors placed within a classroom at least 3 feet away from any wall and atleast $0.5 \mathrm{~m}$ from bookshelves and out of the children's reach. The monitors always placed on the same size and model step ladder/tripod to approximate the breathing zone.

151 parents then asked and to fill up the form about their children's health symptoms. Meanwhile, the school administration permitted an access to the attendance records with notice (emergency leave), due to sickness (enclosed with evidence such as notice or medical certificates) and unnoticed leave. Result then to be analysed using Statistical Package for the Social Sciences package 17.0 (SPSS). Descriptive analysis on Sick Building Symptoms (SBS) and abenteeism, meanwhile correlation on non-parametric using ChiSquare test applies to determine any relation of sickness absentees with the classrooms ventilations modes.

\section{Results and Discussion}

In this section, the SBS of the pupil $(\mathrm{N}=151)$ from selected ten classrooms is reported. Questionnaires were distributed to parents to fill up. This questionnaire represented the pupils' behaviour affected by the classroom's environment. Entire SBS indications of various variables measured to ascertain which factors contributed the most to the symptom. Descriptive analysis was assessed using frequencies with five scales as shown in Table 2 and Figure 1 stated number of days annually reported with SBS. The analysis showed the majority of pupils felt the symptoms of coughing, sore throat and running nose, as these were the common symptoms in this study. The value of these symptoms has a significant association with IAQ.

Table 1. Building characteristics

\begin{tabular}{|c|c|c|c|c|c|c|c|c|c|c|}
\hline \multirow[t]{2}{*}{ Case Study } & \multirow{2}{*}{$\begin{array}{l}\text { S7-56A } \\
\text { R1 }\end{array}$} & \multicolumn{3}{|c|}{ S7-43D } & \multicolumn{2}{|c|}{ SP15 } & \multirow{2}{*}{$\begin{array}{l}\text { KS-SU3 } \\
\text { R1 }\end{array}$} & \multicolumn{3}{|c|}{ PJ-KD3 } \\
\hline & & R1 & $\mathbf{R 2}$ & $\mathbf{R 3}$ & R1 & $\mathbf{R 2}$ & & R1 & $\mathbf{R}$ & $\mathbf{R 3}$ \\
\hline Type of building & $\begin{array}{l}\text { Double } \\
\text { storey terrace } \\
\text { house }\end{array}$ & \multicolumn{3}{|c|}{ Double storey terrace house } & \multicolumn{2}{|c|}{$\begin{array}{l}\text { Double storey } \\
\text { terrace house }\end{array}$} & $\begin{array}{l}\text { Double storey } \\
\text { terrace house }\end{array}$ & \multicolumn{3}{|c|}{ Double storey terrace house } \\
\hline $\begin{array}{c}\text { Age of the } \\
\text { building }\end{array}$ & 8 years & \multicolumn{3}{|c|}{8 years } & \multicolumn{2}{|c|}{13 years } & 2 years & \multicolumn{3}{|c|}{13 years } \\
\hline Location & $\begin{array}{l}\text { Roadside } \\
\text { with less } \\
\text { traffics }\end{array}$ & \multicolumn{3}{|c|}{ Roadside with heavy traffics } & \multicolumn{2}{|c|}{$\begin{array}{l}\text { Roadside with less } \\
\text { traffics }\end{array}$} & $\begin{array}{l}\text { Roadside with } \\
\text { less traffics }\end{array}$ & \multicolumn{3}{|c|}{ Roadside with heavy traffics } \\
\hline
\end{tabular}




\begin{tabular}{|c|c|c|c|c|c|c|c|c|c|c|}
\hline $\begin{array}{l}\text { Surrounding } \\
\text { details }\end{array}$ & $\begin{array}{l}\text { Urban, } \\
\text { residential, } \\
\text { commercial } \\
\text { area }\end{array}$ & \multicolumn{3}{|c|}{$\begin{array}{l}\text { Urban, residential, commercial } \\
\text { area }\end{array}$} & \multicolumn{2}{|c|}{ Urban, Residential } & $\begin{array}{l}\text { Urban, } \\
\text { residential, } \\
\text { commercial } \\
\text { area }\end{array}$ & \multicolumn{3}{|c|}{$\begin{array}{l}\text { Urban, } \\
\text { commercial area }\end{array}$} \\
\hline $\begin{array}{l}\text { Constructional } \\
\text { activity }\end{array}$ & No & \multicolumn{3}{|l|}{ No } & \multicolumn{2}{|l|}{ No } & No & No & No & No \\
\hline $\begin{array}{l}\text { Distance from } \\
\text { main road }\end{array}$ & $\begin{array}{l}500 \mathrm{~m} \text { to } \\
\text { expressway }\end{array}$ & \multicolumn{3}{|l|}{$20 \mathrm{~m}$} & \multicolumn{2}{|l|}{$300 \mathrm{~m}$} & $100 \mathrm{~m}$ & $100 \mathrm{~m}$ & $\begin{array}{l}100 \\
\mathrm{~m}\end{array}$ & $100 \mathrm{~m}$ \\
\hline Operation Hour & $7 \mathrm{am}-7 \mathrm{pm}$ & \multicolumn{3}{|l|}{$7 \mathrm{am}-7 \mathrm{pm}$} & \multicolumn{2}{|l|}{$7 \mathrm{am}-7 \mathrm{pm}$} & $8 \mathrm{am}-5 \mathrm{pm}$ & \multicolumn{3}{|c|}{$8 \mathrm{am}-5 \mathrm{pm}$} \\
\hline Occupancy rate & 18 & 21 & 20 & 16 & 16 & 15 & 15 & 20 & 19 & 18 \\
\hline $\begin{array}{l}\text { Ventilation } \\
\text { status }\end{array}$ & $\begin{array}{l}\text { Natural } \\
\text { ventilation } \\
\text { with ceiling } \\
\text { fan, windows } \\
\text { open }\end{array}$ & \multicolumn{2}{|c|}{ Air-conditional } & $\begin{array}{l}\text { Natural } \\
\text { ventilation } \\
\text { with ceiling } \\
\text { fan, } \\
\text { windows } \\
\text { open }\end{array}$ & \multicolumn{2}{|c|}{$\begin{array}{l}\text { Natural } \\
\text { ventilation with } \\
\text { ceiling fan, } \\
\text { windows open }\end{array}$} & $\begin{array}{l}\text { Natural } \\
\text { ventilation } \\
\text { with ceiling } \\
\text { fan, windows } \\
\text { open }\end{array}$ & \multicolumn{2}{|c|}{$\begin{array}{l}\text { Air- } \\
\text { conditional }\end{array}$} & $\begin{array}{l}\text { Natural } \\
\text { ventilation } \\
\text { with ceiling } \\
\text { fan, } \\
\text { windows } \\
\text { open }\end{array}$ \\
\hline $\begin{array}{l}\text { Number } \\
\text { ceiling fan }\end{array}$ & 1 & 1 & 1 & 1 & 1 & 1 & 1 & 1 & 1 & 1 \\
\hline $\begin{array}{l}\text { Classrooms } \\
\text { conditions } \\
\text { (damage walls, } \\
\text { ceiling, } \\
\text { furniture) }\end{array}$ & $\begin{array}{l}\text { Less dusty } \\
\text { floor } \\
\text { mold stain on } \\
\text { the wall }\end{array}$ & $\begin{array}{l}\text { Mold } \\
\text { stain on } \\
\text { ceiling, } \\
\text { less } \\
\text { dusty } \\
\text { floor }\end{array}$ & $\begin{array}{l}\text { Less } \\
\text { dusty } \\
\text { floor }\end{array}$ & $\begin{array}{l}\text { Less dusty } \\
\text { floor }\end{array}$ & $\begin{array}{l}\text { Dusty } \\
\text { floor } \\
\text { full } \\
\text { with } \\
\text { old } \\
\text { paper }\end{array}$ & $\begin{array}{l}\text { Dusty } \\
\text { floor }\end{array}$ & $\begin{array}{l}\text { Less dusty } \\
\text { floor }\end{array}$ & \multicolumn{3}{|c|}{ Less dusty floor } \\
\hline $\begin{array}{l}\text { Classroom } \\
\text { cleaning }\end{array}$ & $\begin{array}{l}\text { Daily after } \\
\text { school }\end{array}$ & \multicolumn{3}{|c|}{ Daily after school } & \multicolumn{2}{|c|}{ Daily after school } & $\begin{array}{ll}\begin{array}{l}\text { Daily } \\
\text { school }\end{array} & \text { after } \\
\end{array}$ & \multicolumn{3}{|c|}{ Daily after school } \\
\hline $\begin{array}{l}\text { Air-condition } \\
\text { filter cleaning }\end{array}$ & - & \multicolumn{2}{|l|}{ annually } & - & - & - & - & \multicolumn{2}{|c|}{ Annually } & - \\
\hline
\end{tabular}




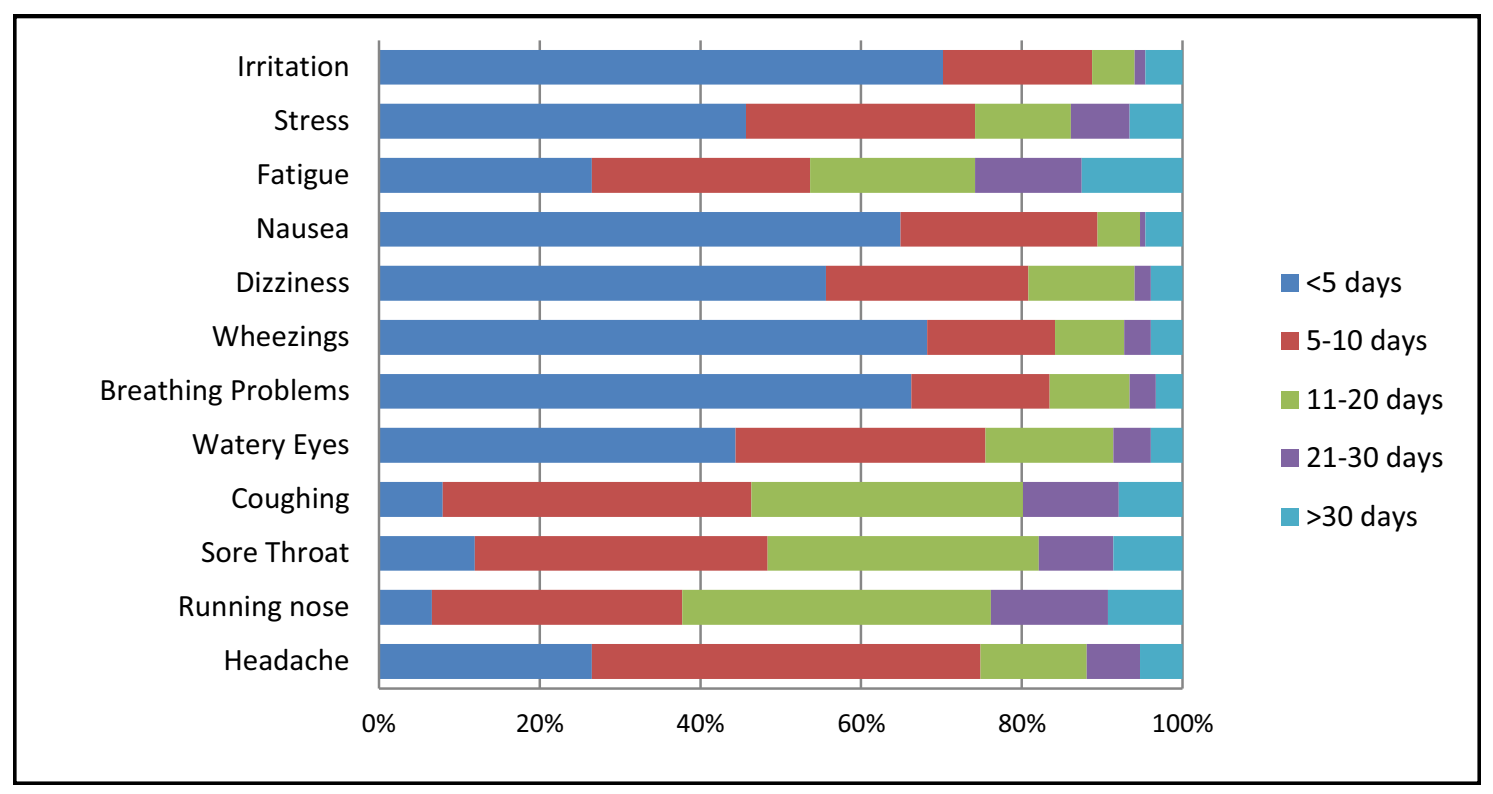

Figure 1. Number of days annually reported with SBS

Table 2. Rating of the symptoms reported annually

\begin{tabular}{|c|c|c|c|c|c|c|c|}
\hline \multirow[t]{2}{*}{$N=151$} & \multicolumn{7}{|c|}{$(\%)$} \\
\hline & never & $\begin{array}{c}\text { TOTAL } \\
\text { UNNOTICEABLE }\end{array}$ & Sometimes & Slightly & Regularly & often & $\begin{array}{c}\text { TOTAL } \\
\text { NOTICEABLE }\end{array}$ \\
\hline Headache & 26.5 & 26.5 & 48.3 & 13.2 & 6.6 & 5.3 & 73.5 \\
\hline Running nose & 6.6 & 6.6 & 31.1 & 33.8 & 9.3 & 8.6 & 82.8 \\
\hline Sore throat & 11.9 & 11.9 & 36.4 & 33.8 & 9.3 & 8.6 & 88.1 \\
\hline Coughing & 7.9 & 7.9 & 38.4 & 33.8 & 11.9 & 7.9 & 92.1 \\
\hline Watery eyes & 44.4 & 44.4 & 31.1 & 15.9 & 4.6 & 4.0 & 55.6 \\
\hline Breathing & 66.2 & 66.2 & 17.2 & 9.9 & 3.3 & 3.3 & 33.8 \\
\hline Wheezing & 68.2 & 68.2 & 15.9 & 8.6 & 3.3 & 4.0 & 31.8 \\
\hline Dizziness & 55.6 & 55.6 & 25.2 & 13.2 & 2.0 & 4.0 & 44.4 \\
\hline Nausea & 64.9 & 64.9 & 24.5 & 5.3 & 0.7 & 4.6 & 35.1 \\
\hline Fatigue & 26.5 & 26.5 & 27.2 & 20.5 & 13.2 & 12.6 & 73.5 \\
\hline Stress & 45.7 & 45.7 & 28.5 & 11.9 & 7.3 & 6.6 & 54.3 \\
\hline Irritation & 70.2 & 70.2 & 18.5 & 5.3 & 1.3 & 4.6 & 29.8 \\
\hline
\end{tabular}


other parameters. When responding about their children, most incidents the parents reported were of dizziness, followed by irritation, watery eyes and nausea. The majority of them were reported to be in

natural ventilation classrooms (S7-56A-R1 and KD06R3). A certain relationship has been described between the eyes and nose that affect each other [16].
Nevertheless, respiratory problems (running nose, sore throat, coughing, breathing problems and wheezing) were most commonly reported in airconditioning classrooms with percentages from $14.9 \%$ to $18.9 \%$. Air conditioners might be a wellspring of indoor contamination if their cleaning is irregular, which can prompt the amassing of dirt in the filters. So, it activates the respiratory indications such as sinusitis, rhinitis, asthma and hypersensitive pneumonitis [17].

Table 3. Noticeable SBS in each classroom

\begin{tabular}{|c|c|c|c|c|c|c|c|c|c|c|}
\hline \multirow{2}{*}{$\begin{array}{l}\text { Percentage } \\
\text { Noticeable SBS } \\
\text { Symptom }\end{array}$} & \multicolumn{10}{|c|}{ Room } \\
\hline & $\begin{array}{l}\text { S7- } \\
\text { 56A- } \\
\text { R1 }^{\text {a }} \\
\end{array}$ & $\begin{array}{l}\text { S7- } \\
\text { 43D- } \\
\text { R1 }^{\text {b }} \\
\end{array}$ & $\begin{array}{l}\text { S7- } \\
\text { 43D- } \\
\text { R2 }^{\text {b }}\end{array}$ & $\begin{array}{l}\text { S7- } \\
\text { 43D- } \\
\text { R3 }^{\mathrm{a}}\end{array}$ & $\begin{array}{l}\text { SP15- } \\
\text { R1 }^{\mathrm{a}}\end{array}$ & $\begin{array}{l}\text { SP15- } \\
\text { R2 }^{\mathrm{a}}\end{array}$ & $\begin{array}{l}\text { SU3- } \\
\text { R1 }^{\text {a }}\end{array}$ & $\begin{array}{l}\text { PJ- } \\
\text { KD6- } \\
\text { R1 }^{\text {b }} \\
\end{array}$ & $\begin{array}{l}\text { PJ- } \\
\text { KD6- } \\
\text { R2 }^{\text {b }} \\
\end{array}$ & $\begin{array}{l}\text { PJ- } \\
\text { KD6- } \\
\text { R3 }^{\mathrm{a}} \\
\end{array}$ \\
\hline Headache & 7.9 & 13.2 & 0.0 & 7.9 & 13.2 & 7.9 & .0 & 15.8 & 10.5 & 23.7 \\
\hline Running nose & 9.6 & 14.9 & 6.4 & 11.7 & 10.6 & 10.6 & 7.4 & 9.6 & 10.6 & 8.5 \\
\hline Sore throat & 6.4 & 16.7 & 6.4 & 11.5 & 9.0 & 11.5 & 9.0 & 10.3 & 9.0 & 10.3 \\
\hline Coughing & 7.4 & 16.0 & 6.2 & 9.9 & 12.3 & 9.9 & 8.6 & 11.1 & 7.4 & 11.1 \\
\hline Watery eyes & 10.8 & 5.4 & 5.4 & 2.7 & 16.2 & 8.1 & 10.8 & 18.9 & 10.8 & 10.8 \\
\hline Breathing & 16.0 & 12.0 & 4.0 & 8.0 & 8.0 & 12.0 & 0.0 & 16.0 & 8.0 & 16.0 \\
\hline Wheezing & 12.5 & 16.7 & 4.2 & 8.3 & 12.5 & 8.3 & 0.0 & 12.5 & 12.5 & 12.5 \\
\hline Dizziness & 10.3 & 6.9 & 6.9 & 10.3 & 10.3 & 3.4 & 0.0 & 6.9 & 17.2 & 27.6 \\
\hline Nausea & 18.8 & 6.3 & 0.0 & 6.3 & 25.0 & 12.5 & 0.0 & 12.5 & 12.5 & 6.3 \\
\hline Fatigue & 10.0 & 10.0 & 5.7 & 7.1 & 7.1 & 10.0 & 8.6 & 10.0 & 15.7 & 15.7 \\
\hline Stress & 10.3 & 7.7 & 5.1 & 5.1 & 10.3 & 7.7 & 7.7 & 15.4 & 12.8 & 17.9 \\
\hline Irritation & 23.5 & 5.9 & 0.0 & 0.0 & 17.6 & 11.8 & 0.0 & 5.9 & 11.8 & 23.5 \\
\hline
\end{tabular}

$\begin{array}{lll}\text { a: NV Classroom } & \text { b: AC Classroom } & \mathrm{N}=151\end{array}$

Table 4 shows the sore throat and fatigue were connected with the classroom's ventilation strategies with $\left(\chi^{2}=6.438, \mathrm{p}<0.005\right),\left(\chi^{2}=4.985, \mathrm{p}<0.005\right)$ and $\left(\chi^{2}=6.438, \mathrm{p}<0.005\right)$, respectively. It specifies that natural ventilation classrooms contributed higher applicable health indications to pupil contrasted with AC classrooms owing to the outside contaminants entering the classrooms through the open windows. On the other hand, the air-conditioned S7-43D-R1 committed the most astounding number of pupils endured the symptoms. Further studies conducted on familial and pupils' history to discover the affiliation of the symptoms.
Table 5 outlines distinct statistics of the absentees' information from the selected classrooms. Figure 2 has indicated that the three highest absentees due to sickness were reported from the air-conditioned classrooms, namely S7-43D-R1, S7-43D-R2 and PJKD3-R2 with the rate of $6.25 \%, 5.46 \%$ and $5.08 \%$ of yearly non-attendance, respectively. Further crosssectional studies about absenteeism, pupil's general particulars, parents' health conditions, pupils' health problems, reported SBS among pupils and houses/dwelling characteristics have been carried out in the other sections of this research study. 
Table 4. Association of ventilation strategies with SBS

\begin{tabular}{lllll}
\hline $\begin{array}{l}\text { Percentage Noticeable SBS } \\
\text { Symptom }\end{array}$ & \multicolumn{2}{c}{ Classroom Vent } & $\chi^{2}$ & $\boldsymbol{P}$ \\
\hline Headache & $37.5 \%$ & $62.5 \%$ & $0.019^{\mathrm{a}}$ & 0.890 \\
Running nose & $10.0 \%$ & $90.0 \%$ & 3.654 & 0.056 \\
Sore throat & $11.1 \%$ & $88.9 \%$ & 6.438 & $0.011^{*}$ \\
Coughing & $8.3 \%$ & $91.7 \%$ & 4.985 & $0.026^{*}$ \\
Watery eyes & $38.8 \%$ & $61.2 \%$ & 0.008 & 0.929 \\
Breathing & $36.0 \%$ & $64.0 \%$ & 0.727 & 0.394 \\
Wheezing & $36.9 \%$ & $63.1 \%$ & 0.315 & 0.574 \\
Dizziness & $34.5 \%$ & $65.5 \%$ & 1.535 & 0.215 \\
Nausea & $35.7 \%$ & $64.3 \%$ & 0.858 & 0.354 \\
Fatigue & $25.0 \%$ & $75.0 \%$ & 6.438 & $0.042 *$ \\
Stress & $41.5 \%$ & $58.5 \%$ & 1.444 & 0.230 \\
\hline
\end{tabular}

*Significant at $\mathrm{P}<.05 \quad \mathrm{~N}=151$

Table 5. Percentage of annual absenteeism

\begin{tabular}{lcccc}
\hline & \multicolumn{2}{c}{ TOTAL \% ABSENCE BY SCHOOL } & TOTAL \\
\hline Classroom & Noticeable & Sick & Unnoticeable & $6.08 \%$ \\
S7-56A-R1* & $1.48 \%$ & $4.27 \%$ & $0.33 \%$ & $\mathbf{9 . 8 8 \%}$ \\
S7-43D-R1** & $\mathbf{2 . 1 2 \%}$ & $\mathbf{6 . 2 5} \%$ & $\mathbf{1 . 5 1 \%}$ & $\mathbf{6 . 4 0 \%}$ \\
S7-43D-R2** & $\mathbf{0 . 6 7 \%}$ & $\mathbf{5 . 4 6 \%}$ & $\mathbf{0 . 2 7 \%}$ & $5.39 \%$ \\
S7-43D-R3* & $1.07 \%$ & $4.03 \%$ & $0.29 \%$ & $8.83 \%$ \\
SP15-R1* & $2.86 \%$ & $4.37 \%$ & $1.61 \%$ & $8.99 \%$ \\
SP15-R2* & $2.96 \%$ & $4.31 \%$ & $1.72 \%$ & $6.90 \%$ \\
SU-R1* & $2.04 \%$ & $4.57 \%$ & $0.28 \%$ & $6.80 \%$ \\
PJ-KD3-R1** & $1.74 \%$ & $4.66 \%$ & $0.39 \%$ & $\mathbf{6 . 7 7 \%}$ \\
PJ-KD3-R2** & $\mathbf{1 . 2 6 \%}$ & $\mathbf{5 . 0 8 \%}$ & $\mathbf{0 . 4 3 \%}$ & $6.74 \%$ \\
\hline PJ-KD3-R3* & $1.82 \%$ & $4.31 \%$ & $0.62 \%$ & \\
\hline
\end{tabular}

*Natural ventilation, ceiling fans and windows open

**Air-conditioning classroom 


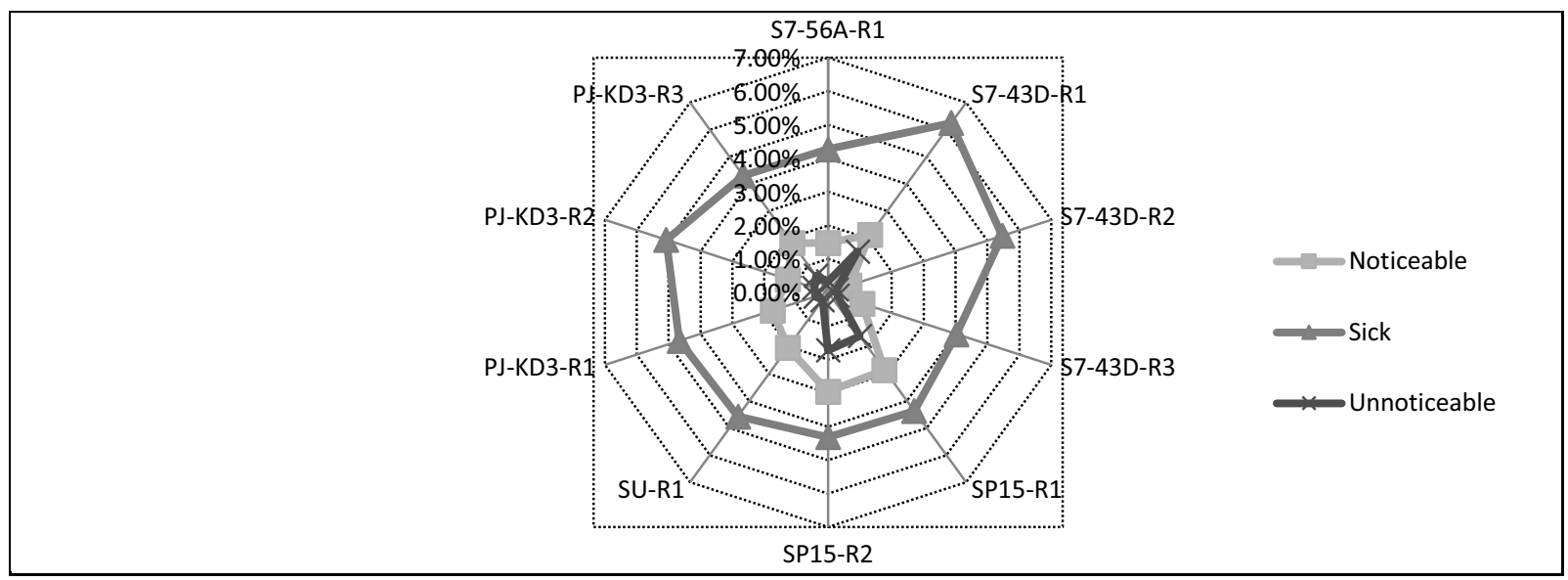

Figure 2. Annual absenteeism according to classroom

The results have proven that the absentees for NV and $\mathrm{AC}$ classrooms did not provide the same value. The air-conditioned classrooms indicated higher rates of annual absentee because of the sickness (Table 6). Nevertheless, there was no link found between the ventilation strategies and annual leave among pupils. The absenteeism in air-conditioned classrooms was higher than the natural ventilation classrooms with $32.8 \%$ of pupils, who were absent for more than 20 days in a year because of sickness belonged to the air conditioned classrooms. The comfort and healthy level is related to the IEQ performance. Good ventilation ensures the comfort level and improve the quality of the learning environment.

Table 6. The annual absentees according to ventilation strategies

\begin{tabular}{|c|c|c|c|}
\hline \multirow[b]{2}{*}{ Classrooms } & \multicolumn{3}{|c|}{ \% Annual Absenteeism: Sickness } \\
\hline & $\begin{array}{l}<3 \% \\
\text { absence } \\
\text { (less } 7 \\
\text { days) }\end{array}$ & $\begin{array}{l}3 \%-6 \% \\
\text { Absenc (7- } \\
20 \text { days) }\end{array}$ & $\begin{array}{l}>6 \% \\
\text { absence } \\
\text { (more } 20 \\
\text { days) }\end{array}$ \\
\hline $\begin{array}{l}\text { Air conditioned } \\
\text { classrooms }\end{array}$ & $32.8 \%$ & $34.5 \%$ & $32.8 \%$ \\
\hline $\begin{array}{l}\text { Naturally } \\
\text { Ventilated } \\
\text { classrooms } \\
\end{array}$ & $40.9 \%$ & $43.0 \%$ & $16.1 \%$ \\
\hline
\end{tabular}

\section{IAQ Characteristics}

The findings of indoors and outdoors IAQ concentrations are summarised in Table 7. For three air condition classrooms (S7-43D-R1, S7-43D-R2 and PJKD6-R1), mean indoor temperature were lower than the corresponding outdoor levels. However, the whole classrooms and respective outdoors stated higher value of mean temperature than the recommended range for acceptable indoor air quality of American Society of Heating, Refrigerating and Air-conditioning Engineers [18] at $23.0^{\circ} \mathrm{C}$ to $26^{\circ} \mathrm{C}$. The $\mathrm{I} / \mathrm{O}$ for temperature of each classroom stated in small value, range between 0.93 -
1.11. Generally, relative humidity in four natural ventilation classrooms (S7-43D-R3, SP15-R1, SP15R2 and KS-SU3-R1) exceeded the [18] recommendation limit at $30 \%-65 \%$. The $\mathrm{I} / \mathrm{O}$ relative humidity of each classroom have shown in small ranging, except the air-condition classroom PJ-KD6$\mathrm{R} 2$ at 0.76 with the lowest ratio indoor-outdoor, suggesting that the mechanical air-conditioner have controlled the indoor environment.

Indoor $\mathrm{CO}_{2}$ concentrations have been referred to as an indicator of indoor air quality. The distribution of $\mathrm{CO}_{2}$ is log-normal. The concentrations of both points (indoor and outdoor) are fluctuated and resulted insignificant to others. Meaning, the outdoor carbon dioxide concentration do not influent the indoor concentration. The mean values of outdoor carbon dioxide range between $326.13 \mathrm{ppm}$ to $488.25 \mathrm{ppm}$. But, the indoor carbon oxide concentration reveals differently. Ventilation strategies and occupant density have given a significant effect to the level of $\mathrm{CO}_{2}$. The air-conditioned S7-43D-R2 classroom with density of 22 pupils stated the highest mean value of $\mathrm{CO}_{2}$ at 1680 ppm, followed by PJ-KD6-R2 air-conditioned classroom with 20 pupils' density at $1295 \mathrm{ppm}, \mathrm{CO}_{2}$ mean value concentration 1293ppm for PJ-KD6-R1 (pupils density: 19 people) and air-conditioned classroom S7-43D-R1( with 19 pupils density) at 1054 ppm of $\mathrm{CO}_{2}$ mean value. These 4 air-conditioned classrooms have exceeded $1000 \mathrm{ppm}$ as stipulated standard limit in The Malaysian Code of Practice [19] and [18] Meanwhile, the natural ventilation classrooms (S7-56A-R1, S7-43D-R3, SP15-R1, SP15-R2, PJ-SU3-R1) seem to have a good indoor air quality, where the indoor $\mathrm{CO}_{2}$ mean value concentrations were [18] and [19] limit. Although, S756A-R1, S7-43D-R1, PJ-KD6-R1 and PJ-KD6-R3 has the similar numbers of pupil density at a time but the mean values of $\mathrm{CO}_{2}$ were vary with different ventilation strategies. 
Indoor concentration for $\mathrm{PM}_{10}$ was stipulated the maximum allowable concentration in inhabitant area standard is $0.15 \mathrm{mg} / \mathrm{m}^{3}$ [19]. The range of mean concentrations was between 41.0 to $342.82 \mu \mathrm{g} / \mathrm{m}^{3}$. The mean values of particulate $10 \mu \mathrm{m}$ for six natural ventilation classrooms (S7-56A-R1, S7-43D-R3, SP15R1，SP15-R2，KS-SU3-R1 and PJ-KD6-R3) were beyond the Malaysian Code of Practice (DOSH, 2005). However, The air-conditioned classrooms have maintained the $\mathrm{PM}_{10}$ level to be below the limit of Malaysia Code of Practice [19]. It clearly shows that the outdoors particles have distributed the $\mathrm{PM}_{10}$ concentration into the indoor environment.

The mean concentrations of $\mathrm{CH}_{2} \mathrm{O}, \mathrm{CO}$ and TVOC well below the Malaysian Code of Practice [19] recommended values of $10 \mathrm{ppm}$ for an 8-hour of exposure. The values were ranging between from undetectable to $0.03 \mathrm{ppm}, 0.26 \mathrm{ppm}$ to $0.83 \mathrm{ppm}$ and 18.5 to $217.13 \mathrm{ppb}$ respectively. The finding shows a few parameters were beyond the standard limit and suspected as a contribution to the health symptoms among occupants. Relative humidity, temperature, $\mathrm{CO}_{2}$ and respiratory particulate, $\mathrm{PM}_{10}$ were found as the inadequate parameters in this study. As mentioned earlier, Malaysia tropics condition might effects the level of temperature and relative humidity. It is impossible to get the adequate level for both environmental parameters.

Running nose, sore throat and coughing were reported higher at both ventilation classrooms. Surprisingly, sore throat, coughing and fatique were significantly perceived in NA classrooms which were recognized with the elevated indoor concentration of $\mathrm{PM}_{10}$, temperature and relative humidity. These parameters might as well contributed to the perceived symptoms among pupils in the classrooms [20]. Thus, it explained the absentees' rates for children in AC classrooms higher than the annual absentees rates among chidren in NV classrooms.

\section{Conclusions}

From this research, it can be concluded that the numbers of annual absentees among pupils in airconditioned classrooms higher than pupils in non-airconditioned classrooms. The natural ventilation classrooms with ceiling fan and opening windows had higher rates of relative humidity. The improper ventilation systems found to be one of the distribute factor to the infectious disease.
Most refurbished preschool building in Malaysia were found not to comply with minimum space regulation concerning children, teachers and staff, leading to the uncomfortable conditions and spreading out the infectious illness. It is suggested that the authorities to take this issues into consideration and provide the sufficient space for the occupants. It is also to put into account the location of the classrooms and schools when the premises being converted to the education buildings.

The other conditions such as dwellings could give significant relations to the absentees' rates. In view of children performance in refurbished private preschools it would be understandable to find that some sources are originated from indoor such as occupants and ventilation strategies. The results of the measurement show the differences arise, due to the advantage of the indoor environment.

Particularly with the high density of pupils in the classrooms in air condition classrooms has invited the high level and insufficient indoor $\mathrm{CO} 2$ and other contaminant sources. This is seen particularly when the high level indoors in the classroom environment contrast strongly with the air outside the preschool building. The adapted space function which previously is bedrooms is inadequately to provide a good air quality and invited few health symptoms. The improper ventilation strategies has encourage some symptoms to children especially to those are really sensitive on the presence of few parameters with the minimum dose. Yet, the symptoms of health problems may not begin when children being at school. The environmental factors such as urbanisation, industrialisation, air pollution, hygienic conditions, renovation, mould and smoke exposures, building and furnishing materials and diet have been related to increased or decreased risk, and thus prevalence, of allergic diseases and could potentially explain a part of the factor. This type of study should be extended to the biological contaminants and widely apply to other numerous of refurbished preschools in order to be better able sustaining the IAQ management strategies and to apply source apportionment methodologies. The outcomes of the studies are foreseen as a benchmark for future research to improve the preschools physicals' environment.

Table 7. Indoors and outdoors IAQ concentrations at every classrooms 


\begin{tabular}{|c|c|c|c|c|c|c|c|c|c|c|}
\hline & \multirow[b]{2}{*}{ 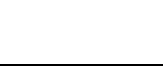 } & & \\
\hline & & Minimum & Maximum & Mean & S.D & Minimum & Maximum & Mean & S.D & \\
\hline \multirow{8}{*}{$\begin{array}{l}\text { Temperature } \\
\left({ }^{\circ} \mathrm{C}\right)\end{array}$} & S7-56A-R1 & 29.70 & 34.90 & 32.31 & 1.49 & 24.10 & 32.70 & 29.12 & 2.89 & 1.11 \\
\hline & S7-43D-R1 & 29.10 & 32.90 & 30.82 & 1.13 & 26.10 & 33.90 & 31.43 & 2.29 & 0.98 \\
\hline & S7-43D-R2 & 27.60 & 31.90 & 29.35 & 1.18 & 26.00 & 34.00 & 31.46 & 2.34 & 0.93 \\
\hline & S7-43D-R3 & 28.00 & 32.60 & 30.57 & 1.34 & 26.60 & 32.80 & 30.51 & 1.55 & 1.00 \\
\hline & SP15-R1 & 27.30 & 33.40 & 30.72 & 1.57 & 20.30 & 33.00 & 29.13 & 3.36 & 1.05 \\
\hline & SP15-R2 & 22.90 & 34.40 & 31.10 & 2.05 & 24.70 & 32.90 & 30.04 & 2.33 & 1.04 \\
\hline & KS-SU3-R1 & 28.10 & 32.20 & 30.26 & 0.92 & 24.90 & 29.90 & 28.14 & 0.99 & 1.08 \\
\hline & PJ-KD6-R1 & 28.20 & 33.20 & 30.52 & 1.50 & 25.90 & 34.70 & 31.42 & 2.25 & 0.97 \\
\hline \multirow{10}{*}{$\begin{array}{l}\text { Relative } \\
\text { Humidity } \\
(\%)\end{array}$} & PJ-KD6-R2 & 29.20 & 31.80 & 30.51 & 0.78 & 22.30 & 32.30 & 28.09 & 2.97 & 1.09 \\
\hline & PJ-KD6-R3 & 29.40 & 33.90 & 32.03 & 1.32 & 26.60 & 35.20 & 31.52 & 2.02 & 1.02 \\
\hline & S7-43D-R2 & 49.90 & 83.00 & 59.09 & 4.91 & 50.90 & 86.10 & 61.39 & 11.30 & 0.96 \\
\hline & S7-43D-R3 & 60.70 & 83.20 & 70.92 & 7.27 & 57.50 & 84.30 & 66.41 & 6.63 & 1.07 \\
\hline & SP15-R1 & 56.00 & 86.70 & 71.40 & 6.56 & 55.20 & 100.90 & 70.95 & 12.34 & 1.01 \\
\hline & SP15-R2 & 40.60 & 90.90 & 72.12 & 8.39 & 58.50 & 98.00 & 70.79 & 10.27 & 1.02 \\
\hline & KS-SU3-R1 & 68.30 & 88.40 & 77.50 & 5.87 & 71.30 & 93.70 & 79.34 & 4.68 & 0.98 \\
\hline & PJ-KD6-R1 & 50.60 & 78.60 & 58.33 & 5.54 & 45.50 & 87.40 & 58.41 & 10.91 & 1.00 \\
\hline & PJ-KD6-R2 & 35.70 & 65.20 & 57.10 & 6.31 & 56.80 & 103.00 & 75.20 & 13.96 & 0.76 \\
\hline & PJ-KD6-R3 & 50.60 & 80.80 & 63.23 & 9.23 & 43.10 & 88.00 & 58.57 & 11.16 & 1.08 \\
\hline \multirow[t]{10}{*}{$\begin{array}{l}\text { Air velocity } \\
\left(\mathrm{ms}^{-1}\right)\end{array}$} & S7-56A-R1 & .00 & 0.50 & 0.05 & 0.09 & 0.00 & 2.00 & 0.22 & 0.23 & 0.22 \\
\hline & S7-43D-R1 & .01 & 0.26 & 0.04 & 0.03 & 0.00 & 1.90 & 0.03 & 0.09 & 1.22 \\
\hline & S7-43D-R2 & .01 & 2.04 & 0.05 & 0.09 & 0.00 & 0.28 & 0.03 & 0.05 & 1.54 \\
\hline & S7-43D-R3 & .01 & 1.68 & 0.06 & 0.11 & 0.00 & 0.25 & 0.03 & 0.04 & 2.15 \\
\hline & SP15-R1 & .00 & 1.97 & 0.23 & 0.22 & 0.00 & 0.48 & 0.01 & 0.03 & 23.37 \\
\hline & SP15-R2 & .00 & 1.97 & 0.23 & 0.22 & 0.00 & 0.48 & 0.01 & 0.03 & 21.79 \\
\hline & KS-SU3-R1 & .01 & 1.58 & 0.02 & 0.09 & 0.00 & 1.07 & 0.12 & 0.16 & 0.20 \\
\hline & PJ-KD6-R1 & .01 & 2.24 & 0.03 & 0.12 & 0.00 & 2.21 & 0.28 & 0.40 & 0.10 \\
\hline & PJ-KD6-R2 & .00 & 3.79 & 0.03 & 0.16 & 0.00 & 3.30 & 0.31 & 0.49 & 0.08 \\
\hline & PJ-KD6-R3 & .00 & 0.02 & 0.00 & 0.00 & 0.00 & 2.89 & 0.28 & 0.41 & 0.00 \\
\hline \multirow[t]{12}{*}{$\mathrm{CO}_{2}(\mathrm{ppm})$} & S7-56A-R1 & 551.70 & 1202.70 & 724.26 & 171.77 & 398.70 & 475.30 & 435.92 & 15.06 & 1.66 \\
\hline & S7-43D-R1 & 521.30 & 2186.00 & 1054.31 & 515.08 & 442.30 & 514.30 & 480.56 & 12.89 & 2.19 \\
\hline & S7-43D-R2 & 526.00 & 4576.70 & 1680.35 & $\begin{array}{c}1184.4 \\
6\end{array}$ & 445.70 & 523.00 & 488.25 & 13.43 & 3.44 \\
\hline & S7-43D-R3 & 418.00 & 1050.30 & 603.18 & 192.83 & 442.30 & 525.00 & 487.11 & 17.93 & 1.24 \\
\hline & SP15-R1 & 449.00 & 662.00 & 537.04 & 48.91 & 338.30 & 447.00 & 393.62 & 26.82 & 1.36 \\
\hline & SP15-R2 & 337.70 & 1005.50 & 640.70 & 123.99 & 344.30 & 463.00 & 404.43 & 27.32 & 1.58 \\
\hline & KS-SU3-R1 & 158.70 & 1276.70 & 699.13 & 288.09 & 147.00 & 526.50 & 326.13 & 100.03 & 2.14 \\
\hline & PJ-KD6-R1 & 509.00 & 2627.50 & 1294.75 & 550.69 & 228.50 & 482.00 & 438.71 & 19.56 & 2.95 \\
\hline & PJ-KD6-R2 & 478.00 & 2709.00 & 1458.78 & 658.08 & 0.00 & 460.00 & 359.60 & 53.99 & 4.06 \\
\hline & PJ-KD6-R3 & 500.00 & 1793.00 & 766.86 & 281.94 & 407.00 & 516.00 & 455.06 & 19.29 & 1.69 \\
\hline & & \multicolumn{4}{|c|}{ Indoor } & \multicolumn{4}{|c|}{ Outdoor } & $\mathrm{I} / \mathrm{O}$ \\
\hline & Classroom & Minimum & $\begin{array}{c}\text { Maximu } \\
\mathrm{m} \\
\end{array}$ & Mean & S.D & Minimum & $\begin{array}{c}\text { Maximu } \\
\mathrm{m} \\
\end{array}$ & Mean & S.D & \\
\hline
\end{tabular}




\begin{tabular}{|c|c|c|c|c|c|c|c|c|c|c|}
\hline \multirow[t]{10}{*}{$\mathrm{CO}(\mathrm{ppm})$} & S7-56A-R1 & 0.00 & 1.00 & 0.32 & 0.33 & 0.00 & 1.70 & 0.31 & 0.35 & 1.02 \\
\hline & S7-43D-R1 & 0.00 & 1.80 & 0.53 & 0.63 & 0.00 & 4.00 & 0.63 & 0.76 & 0.84 \\
\hline & S7-43D-R2 & 0.00 & 1.40 & 0.60 & 0.46 & 0.00 & 1.80 & 0.43 & 0.54 & 1.39 \\
\hline & S7-43D-R3 & 0.00 & 1.30 & 0.39 & 0.44 & 0.00 & 3.00 & 0.50 & 0.62 & 0.78 \\
\hline & SP15-R1 & 0.00 & 1.70 & 0.32 & 0.40 & 0.00 & 2.70 & 0.37 & 0.52 & 0.86 \\
\hline & SP15-R2 & 0.00 & 2.40 & 0.56 & 0.52 & 0.00 & 2.30 & 0.45 & 0.50 & 1.23 \\
\hline & KS-SU3-R1 & 0.00 & 1.10 & 0.26 & 0.31 & 0.00 & 1.20 & 0.44 & 0.36 & 0.59 \\
\hline & PJ-KD6-R1 & 0.00 & 2.00 & 0.46 & 0.64 & 0.00 & 3.00 & 0.26 & 0.54 & 1.77 \\
\hline & PJ-KD6-R2 & 0.00 & 2.60 & 0.83 & 0.66 & 0.00 & 2.00 & 0.12 & 0.19 & 6.72 \\
\hline & PJ-KD6-R3 & 0.00 & 1.40 & 0.31 & 0.43 & 0.00 & 2.70 & 0.25 & 0.58 & 1.25 \\
\hline \multirow[t]{10}{*}{ TVOC(ppb) } & S7-56A-R1 & 47.70 & 145.70 & 105.15 & 26.05 & 0.00 & 326.30 & 5.45 & 31.55 & 19.31 \\
\hline & S7-43D-R1 & 0.00 & 189.00 & 157.49 & 41.16 & 0.00 & 257.00 & 3.02 & 20.55 & 52.14 \\
\hline & S7-43D-R2 & 0.00 & 202.70 & 149.95 & 49.72 & 0.00 & 344.00 & 6.73 & 35.22 & 22.27 \\
\hline & S7-43D-R3 & 0.00 & 96.30 & 51.61 & 35.17 & 0.00 & 424.70 & 2.59 & 25.84 & 19.90 \\
\hline & SP15-R1 & 0.00 & 63.00 & 23.60 & 24.37 & 0.00 & 30659.70 & 643.64 & $\begin{array}{c}3340.1 \\
6\end{array}$ & 0.04 \\
\hline & SP15-R2 & 0.00 & 177.00 & 36.82 & 41.85 & 3.30 & 23331.30 & 1056.85 & $\begin{array}{c}4152.6 \\
4\end{array}$ & 0.03 \\
\hline & KS-SU3-R1 & 0.00 & 52.70 & 18.50 & 18.66 & 0.00 & 5339.50 & 151.82 & 525.74 & 0.12 \\
\hline & PJ-KD6-R1 & 0.00 & 134.50 & 109.28 & 36.33 & 0.00 & 910.50 & 27.26 & 88.64 & 4.01 \\
\hline & PJ-KD6-R2 & 149.00 & 295.00 & 217.13 & 25.77 & 0.00 & 3363.00 & 142.62 & 442.24 & 1.52 \\
\hline & PJ-KD6-R3 & 0.00 & 144.00 & 95.01 & 42.46 & 0.00 & 1005.00 & 30.14 & 98.84 & 3.15 \\
\hline \multirow[t]{10}{*}{$\mathrm{CH}_{2} \mathrm{O}(\mathrm{ppm})$} & S7-56A-R1 & 0.00 & 0.43 & 0.02 & 0.06 & & & & & \\
\hline & S7-43D-R1 & 0.00 & 0.00 & 0.00 & 0.00 & & & & & \\
\hline & S7-43D-R2 & 0.00 & 0.00 & 0.00 & 0.00 & & & & & \\
\hline & S7-43D-R3 & 0.00 & 0.28 & 0.01 & 0.03 & & & & & \\
\hline & SP15-R1 & 0.00 & 0.24 & 0.02 & 0.04 & & & & & \\
\hline & SP15-R2 & 0.00 & 0.28 & 0.01 & 0.03 & & & & & \\
\hline & KS-SU3-R1 & 0.02 & 0.24 & 0.03 & 0.08 & & & & & \\
\hline & PJ-KD6-R1 & 0.00 & 0.00 & 0.00 & 0.00 & & & & & \\
\hline & PJ-KD6-R2 & 0.00 & 0.00 & 0.00 & 0.00 & & & & & \\
\hline & PJ-KD6-R3 & 0.00 & 0.00 & 0.00 & 0.00 & & & & & \\
\hline \multirow[t]{9}{*}{$\begin{array}{c}\mathrm{PM}_{10} \\
(\mu \mathrm{g} / \mathrm{m} 3)\end{array}$} & $\begin{array}{l}\text { S7-56A-R1 } \\
\text { S7-43D-R1 }\end{array}$ & $\begin{array}{c}100.00 \\
30.00\end{array}$ & $\begin{array}{l}566.00 \\
123.00\end{array}$ & $\begin{array}{c}316.24 \\
41.00\end{array}$ & $\begin{array}{c}141.21 \\
23.38\end{array}$ & & & & & \\
\hline & S7-43D-R2 & 31.00 & 144.00 & 69.59 & 21.70 & & & & & \\
\hline & S7-43D-R3 & 62.00 & 273.00 & 158.57 & 67.69 & & & & & \\
\hline & SP15-R1 & 100.00 & 566.00 & 316.24 & 141.21 & & & & & \\
\hline & SP15-R2 & 65.00 & 370.00 & 208.06 & 66.63 & & & & & \\
\hline & KS-SU3-R1 & 115.00 & 556.00 & 342.82 & 123.45 & & & & & \\
\hline & PJ-KD6-R1 & 36.00 & 135.00 & 73.48 & 18.23 & & & & & \\
\hline & PJ-KD6-R2 & 17.00 & 163.00 & 42.64 & 28.17 & & & & & \\
\hline & PJ-KD6-R3 & 95.00 & 909.00 & 174.25 & 73.47 & & & & & \\
\hline
\end{tabular}




\section{Acknowledgements}

The authors gratefully acknowledge the financial support of the Short Term Grant (2016) no. 304/PPBGN/6313274 established by the University Science Malaysia

\section{References}

1 L. Chatzidiakou, D. Mumovic, A.J. Summerfield, What do we know about indoor air quality in school classrooms? A critical review of the literature. Intelligent Buildings International, 4(4), 228-259 (2012)

2 G. Zhang, J. Spickett, K. Rumchev, A.H. Lee, S. Stick, Indoor Environmental Quality in a "Low Allergen" School and Three Standard Primary Schools in Western Australia. Indoor Air. 16, 74-80 (2006)

3 M. Turunen, O. Toyinbo, T. Putus, A. Nevalainen, R. Shaughnessy, R., U. Haverinen-Shaughnessy, Indoor environmental quality in school buildings, and the health and wellbeing of students. International Journal of Hygiene and Environmental Health, 217(7), 733739 (2014)

4 J. Ervasti, M. Kivimäki, I. Kawachi, S. Subramanian, J. Pentti, T. Oksanen, R. Puusniekka, T. Pohjonen, J. Vahtera, M. Virtanen, School environment as predictor of teacher sick leave: data-linked prospective cohort study. BMC Public Health, 12,770-781 (2012)

5

6 R.J. Soughnessy, U.H. Soughnessy, A. Nevalainen, D. Moschandreas, A preliminary study on Association between ventilation rates in classrooms and students performance. Indoor Air, 16, 465-468 (2006)

7 E. Azor-Martanez, Y. Gonzalez-Jimenez, M.L. SeijasVazquez, E. Cobos-Carrascosa, J. SantistebanMartÃnez, J.M. MartÃnez-LÃ̄ ${ }^{3}$ ez, et al. The impact of common infections on school absenteeism during an academic year. American Journal of Infection Control, 42(6), 632-637(2014)

8 N.M. Salleh, S.N. Kamaruzzaman, R. Sulaiman, F.M. Darus, Associate Between Indoor Relative Humidity and Absenteeism at Refurbished Pre-Schools in Malaysia. Advanced Science Letters, 19(10), 2999. 3003 (2013)

9 N.A. Ayuni, J. Juliana M.H. Ibrahim, Exposure to PM10 and NO2 and association with respiratory health among primary school children living near petrochemical industry area at Kertih, Terengganu. Journal of Medical and Bioengineering, 3( 4):282 287 (2014)

10 P.C. Chua, J. Jalaludin, T.R Hamedon, N.M Adam, Preschools' indoor air quality and respiratory health symptoms among preschoolers in Selangor, Procedia Environmental Sciences 30 ( 2015)
11 N. Mohamad, M.T. Latif, M.F. Khan, Source apportionment and health risk assessment of PM10 in a naturally ventilated school in a tropical environment, Ecotoxicology and Environmental Safety, 124(2016)

12 American Lung Association, American Medical Association, US Consumer Product Safety Association and U.S. Environmental Protection Agency. (2004). Indoor air pollution. An introduction to health professionals. New York: Diane Publishing Co.

13 T.L Mohd, M.N. Zafirah, B.M. Mazlin, B.M. "Lead in PM10 and in indoor dust around schools and preschools in Selangor, Malaysia”. Indoor and Built Environment, DOI: 10.1177/1d20326X11402433 (2011)

14 P. Carrer, P. Wargocki, A. Fanetti W. Bischofc, E.D.O. Fernandes, T. Hartmann, S. Kephalopoulos, S. Palkonen, O. Seppänen, What does the scientific literature tell us about the ventilation-health relationship in public and residential buildings?. Building and Environment, 94 (1), 273-286 (2015)

15 G. Kats, National Review of Green Schools. A Report for the Massachusetts Technology Collaborative, 3245(2005)

16 [MOE] Ministry of Education. (2014). Preliminary report: Malaysia education blueprint 2013-2025. Retrieved on 11 September 2014, at http://www.moe.gov.my/userfiles/file/PPP/Preliminary -Blueprint-Eng.pdf

17 J.J. Oppenheimer, The Nose and its Relationship to the Eyes. Curr. Allergy Asthma Rep. 10 (2010)

18 P. Guo, K. Yokoyama, F. Piao, K. Sakai, M. Khalequzzaman, M. Kamijima, et al, Sick Building Syndrome by Indoor Air Pollution in Dalian, China. International Journal of Environmental Research and Public Health, 10(4), 1489-1504 (2013)

19 ASHRAE (2007) Ventilation for Acceptable Indoor Air Quality, Standard 62-2007, American Society for Heating, Refrigerating and Air Conditioning Engineers, Atlanta, GA.

20 DOSH [Department of Safety and Health]. Code of Practice on Indoor Air Quality. ISBN: 983-2014-51-4, JKKP: GP(1)05/2005. Ministry of Human Resources Malaysia. 2010.

21 P.M. Bluyssen, The Indoor Environment Handbook. London: RIBA Publishing. Association (2009) 